\title{
Hydrogenase activity of mineral-associated and suspended populations of Desulfovibrio desulfuricans Essex 6
}

\section{Authors: C. L. Reardon, T. S. Magnuson, E. S. Boyd, W. D. Leavitt, D. W. Reed, G. G. Geesey}

The final publication is available at Springer via http://dx.doi.org/10.1007/s00248-013-0308-y.

Reardon CL, Magnuson TS, Boyd ES, Leavitt WD, Reed DW, Geesey GG, "Hydrogenase activity of mineral-associated and suspended populations of Desulfovibrio desulfuricans Essex 6," Microbial Ecology, 67(2):318-326. 


\title{
Hydrogenase Activity of Mineral-Associated and Suspended Populations of Desulfovibrio desulfuricans Essex 6
}

\author{
C. L. Reardon • T. S. Magnuson • E. S. Boyd • \\ W. D. Leavitt • D. W. Reed • G. G. Geesey \\ C. L. Reardon \\ Columbia Plateau Conservation Research Center, USDA Agricultural Research Service, Adams, OR 97810, USA \\ T. S. Magnuson \\ Department of Biological Sciences, Idaho State University, Pocatello, ID 83209, USA \\ E. S. Boyd \\ Department of Chemistry and Biochemistry, Montana State University, Bozeman, MT 59717, USA \\ D. W. Reed \\ Biological and Chemical Processing Department, \\ Idaho Falls, ID 83415, USA \\ W. D. Leavitt • G. G. Geesey \\ Department of Microbiology, Montana State University, Bozeman, MT 59717, USA \\ C. L. Reardon \\ USDA-ARS, P.O. Box 370, Pendleton, OR 97801, USA
}

\begin{abstract}
The interactions between sulfate-reducing microorganisms and iron oxides influence a number of important redox-sensitive biogeochemical processes including the formation of iron sulfides. Enzymes, such as hydrogenase which catalyze the reversible oxidation of molecular hydrogen, are known to mediate electron transfer to metals and may contribute to the formation and speciation of ferrous sulfides formed at the cell-mineral interface. In the present study, we compared the whole cell hydrogenase activity of Desulfovibrio desulfuricans strain Essex 6 growing as biofilms on hematite (hematite-associated) or as suspended populations using different metabolic pathways. Hematite-associated cells exhibited significantly greater hydrogenase activity than suspended populations during sulfate respiration but not during pyruvate fermentation. The enhanced activity of the hematite-associated, sulfate-grown cells appears to be dependent on iron availability rather than a general response to surface attachment since the activity of glass-associated cells did not differ from that of suspended populations. Hydrogenase activity of pyruvate-fermenting cells was stimulated by addition of iron as soluble $\mathrm{Fe}(\mathrm{II}) \mathrm{Cl} 2$ and, in the absence of added iron, both sulfate-reducing and pyruvate-fermenting cells displayed similar rates of hydrogenase activity. These data suggest that iron exerts a stronger influence on whole cell hydrogenase activity than either metabolic pathway or mode of growth. The location of hydrogenase to the cell envelope and the enhanced activity at the hematite surface in sulfate-reducing cells may influence the redox conditions that control the species of iron sulfides on the mineral surface.
\end{abstract}

\section{Introduction}

Microbes play an important role in the transformation of minerals. Sulfate-reducing bacteria (SRB) are known mediators of mineral transformations based on their ability to produce sulfide [1-3]. Sulfide affects the speciation and solubility of several redox-active, mineral-containing elements including iron ( $\mathrm{Fe}$ ) [4]. The speciation and stability of Fe-containing mineral phases are influenced by several factors including sulfide concentration, aqueous phase $\mathrm{Fe}$ concentration [5], redox potential, and $\mathrm{pH}$ [4], all of which can be affected by microbial activity. As such, it is not surprising that cultivation conditions for SRB influence the speciation and stability of ferrous sulfides (FeS). For example, the FeS species mackinawite and/or greigite are formed during growth of suspended populations of SRB in the presence of soluble iron [6-8] whereas pyrrhotite is formed during growth of SRB as a biofilm on solid phase iron $[5,9]$. 
The formation of pyrrhotite by hematite-associated SRB was hypothesized to result from the establishment of conditions at the cell-mineral interface that differed from those of the bulk aqueous phase since the formation of this mineral (i.e., stability field) was not favored by the latter conditions [5]. The differing conditions may have arisen as a result of variability in cell activity depending on the mode of cell growth (suspended vs. attached) [10-12], or alternatively, if the metabolic products of growth (e.g., $\mathrm{H}^{+}, \mathrm{S}^{2-}$ ) were concentrated at the cell-mineral interface rather than distributed throughout the liquid culture. Despite evidence that suggests that SRB commonly grow in association with solid phases in nature [13-15], characterization of their metabolic activities has been conducted primarily on suspended populations [16-21].

Hydrogenase enzymes are critical components of microbial electron transport chain. Hydrogenases catalyze the reversible reaction $\mathrm{H}_{2} \leftrightarrow 2 \mathrm{H}^{+}+2 \mathrm{e}^{-}$(reviewed in [22]) and are reported to transport electrons directly to metals including iron [23-25]. Two phylogenetically distinct types of hydrogenase are encoded by Desulfovibrio spp., the [FeFe] hydrogenase (referred here on as the [Fe] hydrogenase), and [NiFe] hydrogenase which also includes the [NiFeSe] hydrogenase $[22,26]$. The $[\mathrm{NiFe}]$ and $[\mathrm{Fe}]$ hydrogenases are localized to the periplasm as either membrane-associated or soluble proteins [26-28] and have reportedly different functions. The [NiFe] hydrogenase tends to be involved in $\mathrm{H}_{2}$ consumption whereas the $[\mathrm{Fe}]$ hydrogenase tends to be involved in $\mathrm{H}_{2}$ evolution [22] although the reverse has been observed for both enzymes [17, 29].

Hydrogenase activity of Desulfovibrio sp. is affected by several factors including the availability of Fe(II) [21] and types of electron donor and terminal electron acceptors [20]. Although growth conditions exert strong control on hydrogenase activity, most studies have been conducted in suspended populations respiring sulfate [16-21] and few have focused on cells growing on mineral surfaces [5]. The activity of hydrogenase enzymes $\left(\mathrm{H}_{2}\right.$ generation, proton production, and/or direct metal reduction) in conjunction with the periplasmic location supports the notion that hydrogenase may influence the extracellular conditions immediately adjacent to the cell. This study compared the hydrogenase activity of hematite-associated and suspended cells of Desulfovibrio desulfuricans Essex 6 using two metabolic pathways in an effort to address why the $\mathrm{FeS}$ species formed during growth of SRB are different for suspended and iron oxide mineral-associated populations [5-9]. The results indicate that hematite-associated growth significantly enhanced hydrogenase activity during sulfate respiration but not pyruvate fermentation. The enhanced activity is attributed to an increased availability of $\mathrm{Fe}$ (II) formed from the reduction of hematite $\mathrm{Fe}$ (III) rather than a surface effect.

\section{Materials and Methods}

Cultivation of Organism D. desulfuricans strain Essex 6 (NCIB 8307, ATCC 29577), referred to hereafter as Essex 6, was routinely cultured at $30{ }^{\circ} \mathrm{C}$ in Postgate medium C $[15,30]$ modified to support growth through sulfate respiration or pyruvate fermentation. Sulfate medium (referred to as $\mathrm{SO} 4$ ) contained $0.06 \mathrm{~g} \mathrm{CaCl}_{2} \cdot 2 \mathrm{H}_{2} \mathrm{O}, 0.5 \mathrm{~g} \mathrm{KH}_{2} \mathrm{PO}_{4}, 1.0 \mathrm{~g} \mathrm{NH}_{4} \mathrm{Cl}$, $4.5 \mathrm{~g} \mathrm{Na}_{2} \mathrm{SO}_{4}, 2.0 \mathrm{~g} \mathrm{MgSO}_{4} \cdot 7 \mathrm{H}_{2} \mathrm{O}$, and $5.6 \mathrm{~g}$ Na-lactate $(60 \%$ syrup) in $1 \mathrm{~L}$ of deionized water. Pyruvate medium (referred to as PYR) contained $0.06 \mathrm{~g} \mathrm{CaCl}_{2} \cdot 2 \mathrm{H}_{2} \mathrm{O}, 0.5 \mathrm{~g} \mathrm{KH}_{2} \mathrm{PO}_{4}, 1.0 \mathrm{~g}$ $\mathrm{NH}_{4} \mathrm{Cl}, 1.6 \mathrm{~g} \mathrm{MgCl}_{2} \cdot 6 \mathrm{H}_{2} \mathrm{O}$, and $3.5 \mathrm{~g}$ Na-pyruvate in $1 \mathrm{~L}$ of deionized water. Both media were adjusted to $\mathrm{pH} 7.2$ with $\mathrm{NaOH}$, dispensed in glass serum bottles, purged of $\mathrm{O}_{2}$ by flushing with $\mathrm{N}_{2}$ gas, and the bottles sealed with butyl rubber stoppers, and autoclaved. Each medium was supplemented with $1 \mathrm{~mL}$ of filter-sterilized deoxygenated amino acid and vitamin solution to achieve final concentrations of $0.02 \mathrm{mg} \mathrm{L}^{-1}$ biotin and folic acid, $0.1 \mathrm{mg} \mathrm{L}^{-1}$ riboflavin, $p$-aminobenzoic acid, pantothenic acid, and cyanocobalamin, $0.2 \mathrm{mg} \mathrm{L}^{-1}$ thiamine and niacin, $0.5 \mathrm{mg} \mathrm{L}^{-1}$ pyridoxine, and $0.02 \mathrm{~g} \mathrm{~L}^{-1} \mathrm{~L}$-arginine, L-serine, and L-glutamic acid [31]. Culture medium supplemented with $50-100 \mathrm{mg}$ of glass beads or $200 \mathrm{mg}$ of $1-$ $2 \mathrm{~mm}$ size-sieved jewelry-grade hematite particles $\left(\alpha-\mathrm{Fe}_{2} \mathrm{O}_{3}\right)$ was prepared as $5 \mathrm{~mL}$ volumes in $10 \mathrm{~mL}$ vials. Sulfate medium containing hematite or glass beads is referred to as "Hem-SO4" or "Glass-SO4," respectively. Pyruvate medium containing hematite is referred to as "Hem-PYR."

Enzyme Assay Whole-cell hydrogenase activity was determined spectrophotometrically using the methyl viologen hydrogen consumption assay [32,33]. The reaction mixture of $1 \mathrm{mM}$ methyl viologen (MV) and $5 \mathrm{mM}$ glucose in $20 \mathrm{mM}$ Tris buffer ( $\mathrm{pH}$ 7.8) was contained in capped cuvettes and purged with $\mathrm{H}_{2}$ for $20 \mathrm{~min}$. Sodium dithionite $(100 \mu \mathrm{M}$, final conc.) was added as a reductant and the solution was purged for an additional $10 \mathrm{~min}$. Glucose oxidase (1U) was added to scavenge any residual oxygen and the reaction mixture purged for 10 min. Cuvettes were purged continuously with $\mathrm{H}_{2}$ during and briefly following sample addition and the caps sealed with electrical tape prior to measurement. Two-weekold cultures were used for enzyme activity determinations. Suspended cells were harvested by syringe and assayed twice from duplicate cultures. Attached populations were harvested by transfer of the hematite or glass beads using forceps to the assay cuvette. Hematite-associated cells were sampled once from each duplicate culture and glass-associated cells twice from duplicate cultures. Methyl viologen reduction was continuously monitored at $604 \mathrm{~nm}\left(\varepsilon_{604}=13.9 \mathrm{mM} \mathrm{cm}^{-1}\right)$ in which $1 \mathrm{U}$ of hydrogenase activity resulted in the consumption of $2 \mu \mathrm{mol}$ of MV per min [32,33]. Assay controls were carried out in the absence of cells with either sterile medium or hematite particles. 
Whole cell hydrogenase activity was expressed in terms of the amount of DNA present in the volume of sampled liquid culture or in terms of the amount of DNA associated with the surfaces (hematite or glass) after the enzyme assay. The use of conventional turbidometric or cell count methods to compare cell densities was precluded due to the non-planar surface properties of the hematite and glass beads. No effort was made to determine the surface area of the hematite particles or glass beads; therefore, it was not possible to compare enzyme activity per unit area for surface attached cells or to compare the area of colonized surface to the liquid volume of the culture. DNA was quantified using the PicoGreen dsDNA Quantification Assay and Qubit dsDNA HS Assay (Invitrogen, Carlsbad, CA). Attached populations were harvested by transfer of the hematite- or glass beads directly from the hydrogenase assay cuvette to PCR tubes containing $50 \mu \mathrm{L}$ of nuclease-free water. For suspended populations, $50 \mu \mathrm{L}$ of culture was transferred to PCR tubes. Cells were lysed by heating at $99{ }^{\circ} \mathrm{C}$ for $15 \mathrm{~min}$ in a thermocycler and DNA assayed from the lysate according to the manufacturer's protocol.

The effect of Fe(II) on hydrogenase activity was assessed in hematite-free PYR cultures since the added Fe(II) would rapidly react with sulfide produced in sulfate-containing medium. $\mathrm{FeCl}_{2}$ and $\mathrm{Na}_{2} \mathrm{~S}$ stock solutions were prepared in ultrapure $\mathrm{H}_{2} \mathrm{O}\left(18.2 \mathrm{M} \Omega-\mathrm{cm} \mathrm{H}_{2} \mathrm{O}, \mathrm{pH}\right.$ 5.6), purged with $\mathrm{N}_{2}$ and filter-sterilized. No precipitation was visible in either stock solution. PYR medium was supplemented with final concentrations of $0,50,100$, and $150 \mu \mathrm{M} \mathrm{FeCl}_{2}$ in which no precipitation was observed after addition of the $\mathrm{FeCl}_{2}$. Half of the medium was transferred to a new sterile $\mathrm{N}_{2}$-purged bottle and $1 \mathrm{mM} \mathrm{Na}_{2} \mathrm{~S}$ (final concentration) was added to precipitate the soluble $\mathrm{Fe}$ (II) from the medium.

The cellular location of hydrogenase was evaluated using the $\mathrm{CuCl}_{2}$ inhibition method in which $1 \mathrm{mM} \mathrm{N}_{2}$-purged $\mathrm{CuCl}_{2}$ ( $\mathrm{pH}$ 7.0) was added to suspended sulfate-reducing cultures 15 min prior to measurement of enzyme activity [34].

$\mathrm{Fe}$ Analysis Iron concentration in the inoculated and sterile media was quantified using the ferrozine assay [35]. Briefly, $0.1 \mathrm{~mL}$ of medium was mixed with $1 \mathrm{~mL}$ of ferrozine reagent $(0.1 \%$ ferrozine in $50 \mathrm{mM}$ HEPES, $\mathrm{pH} 7.0)$ and the absorbance read at $562 \mathrm{~nm}$ after a 5-15-min incubation. Since suspended FeS precipitates formed during sulfate reduction and/or suspended cells interfered with the absorbance readings, these fractions were removed from the medium by either filtering through a $0.2 \mu \mathrm{M}$ filter immediately after addition of the ferrozine reagent or by briefly centrifuging the medium at $10,000 \times g$ before mixing ferrozine reagent with the supernatant. Total $\mathrm{Fe}$ was assessed using the ferrozine assay in which $\mathrm{Fe}$ (III) was initially reduced to $\mathrm{Fe}$ (II) by an overnight reaction with $1 \%$ hydroxylamine. $\mathrm{Fe}(\mathrm{II})$ concentrations were determined by comparison of the absorbance values to those of a standard curve of known concentrations of ferrous ammonium sulfate.

Statistical Analysis The data were analyzed in SAS 9.2 (SAS Institute, Cary, N.C.) by a PROC GLIMMIX procedure for means separation and multiple comparisons with a TukeyKramer adjustment to minimize Type I errors [36]. Correlation between hydrogenase activity and $\mathrm{Fe}$ was assessed using the PROC CORR procedure.

RNA Extraction RNA was extracted from suspended and hematite-associated cells recovered from cultures in the exponential phase of growth using the RNeasy-Mini kit (Qiagen, Valencia, CA) in conjunction with the QiaShredder (Qiagen) according to manufacturer's protocol. Hematiteassociated cells were rinsed briefly with sterile anaerobic medium, lysed and the cell fraction transferred to the QiaShredder. RNA extracts were treated with RNase-free DNase $(0.1 \mathrm{U}$ DNase per $1 \mu \mathrm{L}$ RNA, Promega) for $30 \mathrm{~min}$ and the DNase was heat-inactivated. RNA quality was verified by denaturing agarose gel electrophoresis [37].

Reverse Transcription-PCR (RT-PCR) Transcripts of the genes encoding the large subunits of the $[\mathrm{NiFe}]$ and $[\mathrm{Fe}]$ hydrogenase were detected in RNA extracts using coupled reverse transcription PCR (RT-PCR) (Access RT-PCR System, Promega, Madison, WI). RT-PCR reactions contained $1 \mathrm{X}$ AMV/Tfl $5 \mathrm{X}$ reaction buffer, $0.2 \mathrm{mM}$ dNTP mix, $1 \mathrm{mM} \mathrm{MgSO}_{4}, 5 \mathrm{U}$ AMV reverse transcriptase, $5 \mathrm{U}$ Tfl DNA polymerase, and $1 \mu \mathrm{M}$ forward and reverse primers. A 440-bp fragment of the [NiFe] hydrogenase gene was amplified using the primers Hyd1F (5'-CGC GAC GCC CAG CAC TTC ACC CAG-3') [38] and a truncated version of Hyd5R (5'-GCA GGG CTT CCA GTA GTG GGC GGT GGC GA-3') [38]. The [Fe] hydrogenase was amplified using primers Fe3F (5'-ACC TCG TGC TGC CCC GGC TGG-3') [39] and Fe8R (5'-GCA GGC CAT RAA CTC GAT GAA RTG-3') which was designed complementary to aligned sequences of Desulfovibrio vulgaris, Desulfovibrio fructosovorans, and Desulfovibrio alaskensis G20 to yield a 580-bp region of the gene. RT-PCR was performed by the following thermal cycling protocol: reverse transcription at $45{ }^{\circ} \mathrm{C}(45 \mathrm{~min})$, enzyme inactivation at $94{ }^{\circ} \mathrm{C}(2 \mathrm{~min})$, and 40 cycles of amplification at $94^{\circ} \mathrm{C}(1 \mathrm{~min}), 60^{\circ} \mathrm{C}(1 \mathrm{~min})$, and $68^{\circ} \mathrm{C}(2 \mathrm{~min})$ followed by a final extension step at $68^{\circ} \mathrm{C}$ (7 min). RNA extracts were analyzed by PCR to verify complete digestion of DNA.

In Situ Reverse Transcription-PCR (IS RT-PCR) IS RT-PCR of hematite-associated cells was performed according to published protocols [40, 41]. Briefly, hematite particles were transferred immediately from culture vials to microcentrifuge tubes containing $4 \%$ paraformaldehyde and fixed overnight at 
$4{ }^{\circ} \mathrm{C}$. Particles were washed by three gentle exchanges of $1 \times$ nuclease-free phosphate buffered saline (PBS, pH 7.2) and the cell membranes permeabilized for $30 \mathrm{~min}$ at room temperature with $500 \mu \mathrm{g} \mathrm{mL}^{-1}$ lysozyme. Following three additional PBS exchanges, the particle-associated cells were treated with $20 \mathrm{U}$ of RQ1 RNase-free DNase (Promega) at a final volume of $200 \mu \mathrm{L}$ and stored at $-20^{\circ} \mathrm{C}$ in nuclease-free $\mathrm{H}_{2} \mathrm{O}$ until further analysis. Reverse-transcription PCR was carried out as above with the inclusion of $1 \mu \mathrm{M}$ IRIS-Fuchsia labeled dUTP (Cyanine Technologies, Torino, Italy) to the PCR cycle for direct visualization of cells containing transcript by epifluorescence microscopy. Amplification product was analyzed by agarose gel electrophoresis of the reaction mixture. To ensure the labeling was specific for transcriptcontaining cells and not genomic DNA contamination, reactions were performed in the absence of reverse transcriptase. Additionally, to verify that PCR product released from transcript-containing cells did not re-associate with neighboring non-transcript-containing cells, colonized hematite particles that were treated with paraformaldehyde, lysozyme, and DNase were incubated with IRIS-Fuchsia labeled PCR product.

Microscopy Hematite particle-associated cells subjected to IS RT-PCR were stained for nucleic acid with $10 \mu \mathrm{g} \mathrm{mL}^{-1} 4^{\prime}, 6-$ diamidino-2-phenylindole dihydrochloride (DAPI) for $15 \mathrm{~min}$, destained in fresh, nuclease-free $\mathrm{H}_{2} \mathrm{O}$ for $10 \mathrm{~min}$, and air-dried before viewing with an Olympus BX60 system microscope equipped with $100 \mathrm{~W}$ Hg-vapor discharge lamp and $100 \times$ oil immersion objective. MWU and MWIG filter cubes (Olympus America Inc., Melville, NY) were used to visualize DAPIstained and IRIS-Fuchsia-labeled cells, respectively. Images were captured by an ImagePoint monochrome, Peltier cooled $\left(+10^{\circ} \mathrm{C}\right) \mathrm{CCD}$ camera (Photometrics Ltd., Tuscon, AZ) and Image-Pro Plus software (Media Cybernetics, Silver Springs, MD).

Sequence Analysis DNA was extracted from sulfate-reducing cultures using the Ultraclean Microbial DNA Isolation kit (Mo Bio Laboratories, Carlsbad, CA). The gene encoding the large subunit of the $[\mathrm{NiFe}]$ hydrogenase was amplified using the primers Hyd1F and Hyd7R (5'-CGC AGG CGA TGC ASG GGT C-3') [38] specific for a $\sim 1,400$-bp region. PCR product was purified and sequenced with primers Hyd1F, Hyd7R and internal primers Hyd900R (5'-GGG AGC CTT GAG CCA GGA ATA A-3') and Hyd860F (5'-GCG AAA CCA AAC CCT TCT TCA CCA-3') to yield $2 \times$ coverage. The full sequence of the $[\mathrm{Fe}]$ hydrogenase small and partial large subunit was obtained by genome fractionation and cloning. The restriction enzyme EcoRV was used to fragment genomic DNA based on the results of an in silico digest of the [Fe] hydrogenase cassette which identified the enzyme as a potential non-cutter. The fragments were separated by gel electrophoresis and size fractions were purified using the PureLink Quick Gel Extraction kit (Invitrogen). The gel fraction with the highest abundance of the $[\mathrm{Fe}]$ hydrogenase gene as determined by PCR was cloned into the pJET1.2 vector using the CloneJET PCR Cloning Kit (Fermentas Inc., Glen Burnie, Maryland) and propagated in E. coli Top10 according to the manufacturer's protocol. Sequencing was performed by Beckman Coulter Genomics (Danvers, MA) using an ABI 3730xl DNA Sequencer (Applied Biosystems, Carlsbad, CA). Sequences were assembled and edited in Bioedit software (ver. 7.0.5.3) [42]. Nucleotide sequences were compared to previously deposited nucleotide and amino acid sequences in the NCBI database using the Blastn and Blastx tools (http://www.ncbi.nlm.nih.gov/blast/). The $[\mathrm{NiFe}]$ and $[\mathrm{Fe}]$ hydrogenase sequences are accessible in GenBank and EMBL under accession numbers HQ228172 and HQ228171, respectively.

\section{Results}

Whole Cell Hydrogenase Activity Whole cell hydrogenase activity in hematite-associated (attached) Essex 6 populations respiring sulfate was over fourfold higher $(P<0.0001)$ than that exhibited by suspended cells in the same culture (Fig. 1). By contrast, there was no significant difference in enzyme activity in attached and suspended populations when glass beads were substituted for hematite as a substratum for colonization in Glass-SO4 medium $(P=0.782$; Fig. 1$)$.

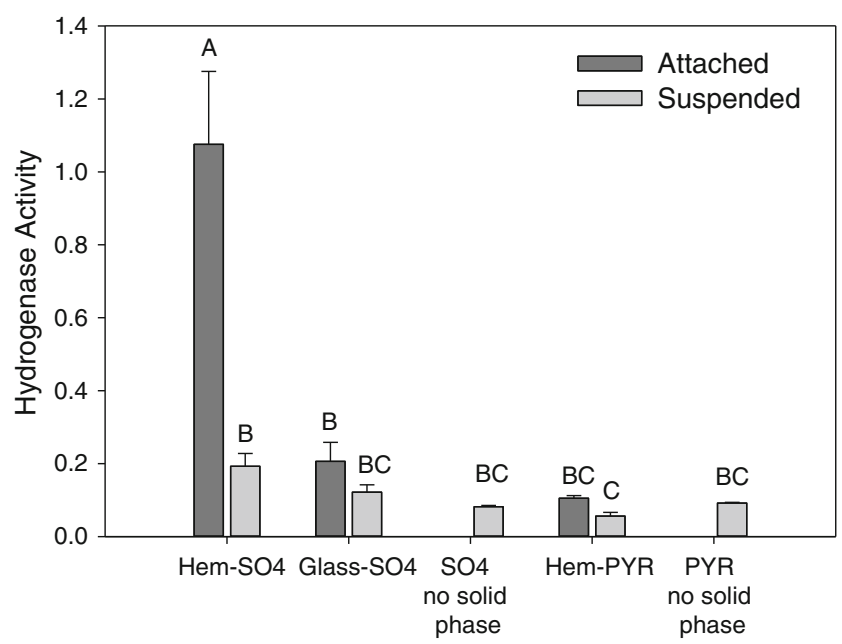

Fig. 1 Hydrogenase activity of suspended and attached populations of D. desulfuricans Essex 6 cultivated in SO4 or PYR medium with hematite (Hem), glass, or without added solid phase. Units of hydrogenase activity are displayed as $\mathrm{mM}$ MV reduced $\mathrm{min}^{-1} \mu \mathrm{g}^{-1}$ DNA and values indicate the mean \pm standard error $(n=2)$. Bars with a common letter above represent values that are not significantly different at $P=0.05$ 
The metabolic pathway used by cells for energy production influenced the extent to which cell attachment to hematite stimulated whole cell hydrogenase activity. The activity of hematite-associated cells cultured fermentatively on pyruvate in Hem-PYR medium was not significantly different from the activity of suspended cells of the same culture $(P=0.919$, Fig. 1). Furthermore, both hematite-attached and suspended cells demonstrated greater hydrogenase activity when reducing sulfate in $\mathrm{Hem}-\mathrm{SO} 4$ medium than when fermenting pyruvate in Hem-PYR medium $(P>0.0001$ for attached populations, $P=0.017$ for suspended populations). In the absence of hematite, no significant difference was observed between cells respiring sulfate ( $\mathrm{SO} 4$ medium) and fermenting pyruvate (PYR medium; $P=1.000$; Fig. 1). Measurable activity and cell growth were not detected on glass beads in the PYR medium (data not shown).

The metabolic pathway used by cells for energy production influenced the soluble iron concentration in the culture medium. In the Hem-PYR cultures, soluble Fe predominately in the form of $\mathrm{Fe}(\mathrm{II})$ accumulated at concentrations ranging from approximately 9 to $410 \mu \mathrm{M}$ (Table 1, Fig. 2). Soluble $\mathrm{Fe}(\mathrm{II})$ and total soluble Fe did not accumulate in the aqueous phase of the Hem-SO4 medium (Table 1). The low concentration of soluble iron in sulfate-respiring cultures was likely due to iron sequestration and precipitation by sulfide formed during sulfate reduction as evidenced by a fine suspension of black precipitate in cultures with prolonged incubation. The small amount of iron detected in sterile hematite-containing media was likely due to chemically mediated mineral dissolution or trace contamination of chemicals, water and/or glassware (Table 1).

\section{Effect of Soluble Iron Concentration on Hydrogenase Enzyme} Activity Although a high degree of variability in hydrogenase activity was measured between the suspended cells of individual Hem-PYR cultures $(n=4, P<0.0001)$, the activity

Table 1 Quantification of iron released from hematite particles in sterile HEM-SO4 and HEM-PYR medium and cultures of $D$. desulfuricans Essex 6

\begin{tabular}{lll}
\hline & $\mathrm{Fe}(\mathrm{II}), \mu \mathrm{M}$ & Total Fe, $\mu \mathrm{M}$ \\
\hline Hem-SO $_{4}$, sterile $^{\mathrm{a}}$ & 2.4 & 2.5 \\
Hem-PYR, sterile $^{\mathrm{a}}$ & 1.1 & 3.8 \\
Hem-SO $_{4}$, culture & $\mathrm{BD}$ & $3.3 \pm 0.8$ \\
Hem-PYR, culture $^{\mathrm{b}}$ & $9.8 \pm 2.0$ & $9.1 \pm 5.1$ \\
\hline
\end{tabular}

Cultures were incubated approximately 2 weeks prior to analysis. Values for cultures indicate mean \pm standard deviation $(n=2)$

${ }^{\text {a }}$ Single culture measurement

${ }^{\mathrm{b}}$ Values presented are from cultures summarized in Fig. 1. Fe(II) concentrations measured from repeated experiments ranged from 8.4 to $407 \mu \mathrm{M}$ (Fig. 2)

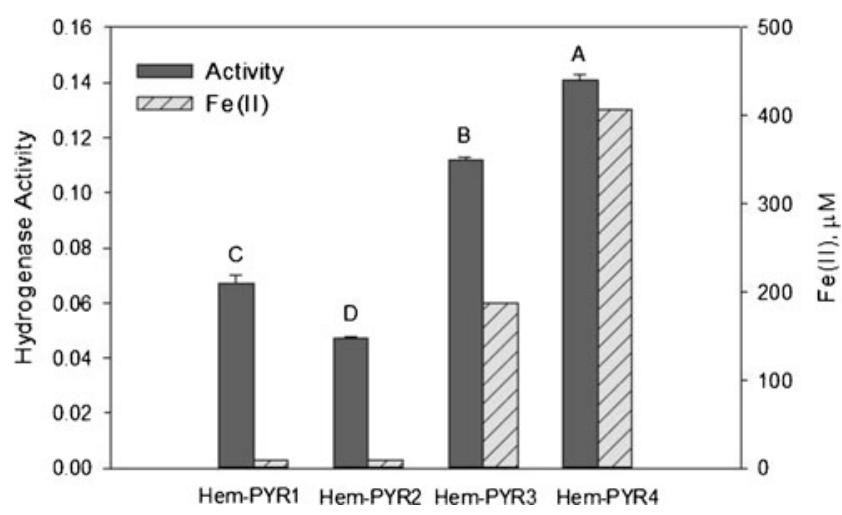

Fig. 2 Hydrogenase activity of suspended populations of $D$. desulfuricans Essex 6 cultured in Hem-PYR medium. The solid bars indicate the mean \pm standard error of duplicate hydrogenase activity measurements from individual cultures (left axis, mM MV reduced $\min ^{-1} \mu \mathrm{g}^{-1}$ DNA). Hatched bars indicate the iron concentrations measured in the individual cultures (right axis). Bars with a common letter above represent values that are not significantly different at $P=0.05$. The mean of Hem-PYR1 and Hem-PYR2 is shown in Fig. 1

was strongly correlated to the Fe(II) concentration $(r=0.96$, $P=0.0002$; Fig. 2). To evaluate whether the enhanced hydrogenase activity measured in the Hem-PYR cultures with elevated $\mathrm{Fe}$ (II) concentration was due to stimulation by the $\mathrm{Fe}$, the enzyme activity was assessed in cells cultured in hematitefree PYR medium amended with either $\mathrm{FeCl}_{2}$ or $\mathrm{FeCl}_{2}$ and $\mathrm{Na}_{2} \mathrm{~S}$. Sulfide was added to the culture medium to precipitate the $\mathrm{Fe}(\mathrm{II})$; however, the removal of $\mathrm{Fe}$ (II) was incomplete (Fig. 3). The addition of sulfide did not have a significant effect on the hydrogenase activity of cells cultured in the absence of $\mathrm{FeCl}_{2}\left(P=0.204\right.$ ). When $150 \mu \mathrm{M} \mathrm{FeCl}_{2}$ (no sulfide) was added

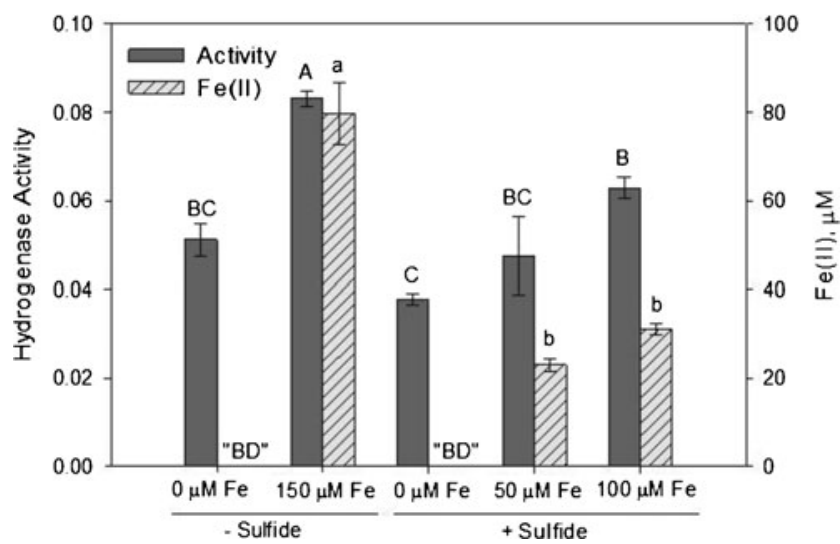

Fig. 3 Hydrogenase activity of suspended populations of $D$. desulfuricans Essex 6 cultured in PYR medium supplemented with different concentrations of $\mathrm{FeCl}_{2}$ in the presence ( + Sulfide) or absence (- Sulfide) of $1 \mathrm{mM} \mathrm{Na}_{2} \mathrm{~S}$. The solid bars indicate the mean \pm standard error of hydrogenase activity (left axis, $\mathrm{mM}$ MV reduced $\mathrm{min}^{-1} \mu \mathrm{g}^{-1}$ DNA), while the hatched bars show the soluble Fe(II) concentration (right axis) measured at the time of hydrogenase activity $(n=2)$. Bars with a common letter above represent values that are not significantly different at $P=0.05$ and letter case is reserved for comparisons among activity (uppercase) and $\mathrm{Fe}(\mathrm{II})$ concentration (lowercase). "BD" indicates the values were below detection 
to the culture medium, the hydrogenase activity of cells increased approximately $62 \%$ compared to cells cultured in the absence of $\mathrm{FeCl}_{2}(P=0.001)$. Similarly, hydrogenase activity was stimulated in cells cultured in medium supplemented with $\mathrm{FeCl}_{2}$ and $\mathrm{Na}_{2} \mathrm{~S}$ in which the $\mathrm{Fe}$ (II) concentrations at the time of the activity assay were reduced by nearly half of the starting concentration. Hydrogenase activity of the cells supplemented with $\mathrm{Na}_{2} \mathrm{~S}$ increased $25 \%$ by the addition of $50 \mu \mathrm{M} \mathrm{FeCl}_{2}$ and $66 \%$ by the addition of $100 \mu \mathrm{M} \mathrm{FeCl}_{2}$ compared cells culture in the absence of $\mathrm{FeCl}_{2}$ (Fig. 3).

Cellular Location of Hydrogenase Hydrogenase activity mediated by enzymes located outside but not inside the cytoplasmic membrane has been shown to be inhibited by the addition of $\mathrm{CuCl}_{2}$ in whole cell assays [34]. Hydrogenase activity was below detection level in SO4- and PYR-grown cells pre-incubated with $1 \mathrm{mM} \mathrm{CuCl}_{2}$ (data not shown). These results suggest that the whole cell activity measured in this study was mediated by enzymes located outside the cytoplasmic membrane in the cell envelope. In addition, translation of the small subunit [Fe] hydrogenase gene sequence revealed the presence of the twin-arginine translocation signal peptide ([S/T]RRxFLK) $[22,43]$. The peptide sequence TRRGFLK was located 5 amino acids from the $\mathrm{N}$ terminus of the protein and supports a periplasmic location for the enzyme.

Gene Expression of Hydrogenase Transcripts of both [NiFe] and $[\mathrm{Fe}]$ hydrogenase were detected in whole cell RNA extracts of both suspended and hematite-associated populations in Hem$\mathrm{SO} 4$ media (data not shown). To determine whether a portion or all of the cells attached to hematite expressed at least one of the hydrogenase enzymes, cells on the mineral surface were visualized using IS RT-PCR. The [NiFe] hydrogenase gene was selected for analysis based on a report by Steger et al. [44] which indicated that the enzyme was up-expressed in Essex 6 cells cultured in lactate-sulfate medium. Cells which stained positive for nucleic acid (DAPI) were also labeled by IRISFuchsia indicating that essentially all cells attached to the hematite surface expressed the [NiFe] hydrogenase gene (Fig. 4, panel a). IRIS-Fuchsia labeling was specific for the gene transcripts and not due to genomic DNA contamination since none of the DAPI-stained cells was labeled in the absence of reverse transcriptase (Fig. 4, panel b). While a sufficient quantity of IS RT-PCR product was retained within the permeabilized cells to allow for observation by epifluorescence microscopy, PCR product of the same amplicon size was also recovered from the solution phase of the reaction mixture suggesting that PCR product leaked from the cells during or following thermocycling. In order to ensure that false positive labeling did not occur from re-association of extracellular PCR product to non-hydrogenaseexpressing cells, fixed, permeabilized, lysozyme and DNasetreated particle-associated cells were incubated with IRIS-
Fuchsia-labeled PCR product and evaluated for fluorescence. None of the DAPI-stained cells visible on the hematite surface were labeled with IRIS-Fuchsia, indicating that only hydrogenase gene-expressing cells exhibited IRIS-Fuchsia fluorescence (Fig. 4, panel c).

\section{Discussion}

Numerous studies have reported that surface-associated microbes exhibit increased activity and/or growth relative to that of suspended populations; however, the enhanced activity conferred by the solid surface has often been indirectly attributed to changes in the medium (i.e., nutrient availability, $\mathrm{pH}$; reviewed in ref. [45]). In this study, we demonstrated that enhanced hydrogenase activity of hematite-associated populations of the sulfate-reducing bacterium $D$. desulfuricans Essex 6 compared to suspended populations was related to hematite iron availability rather than a generalized surface effect. Although it is highly difficult to predict the exact conditions at the mineral-microbe interface, it is likely that the form and local concentration of Fe differed in the hematite-containing cultures for cells attached to the surface and those in suspension.

Dissolution and reduction of the hematite Fe(III) were apparent in sulfate-reducing cultures with prolonged incubation by the formation of a fine suspension of black $\mathrm{FeS}$ precipitates in the medium. The abiotic reaction of sulfide and $\mathrm{Fe}(\mathrm{II})$ occurs rapidly, with one study reporting an immediate $83 \%$ decrease in $\mathrm{Fe}(\mathrm{II})$ upon addition of SRB inoculum containing dissolved $\mathrm{H}_{2} \mathrm{~S}$ [21]. In a report by Neal et al. [5], FeS formation in an SRB culture was limited to the hematite surface suggesting that Fe released from the mineral reacted rapidly with sulfide thus preventing diffusion of soluble Fe(II) to the culture suspension. In the current study, aqueous $\mathrm{Fe}(\mathrm{II})$ in the Hem-SO4 culture was reduced below background (sterile media) indicating that soluble Fe released from the hematite was likely concentrated near the mineral surface compared to the bulk suspension albeit transiently since any $\mathrm{Fe}(\mathrm{II})$ would have rapidly reacted with sulfide. Therefore the suspended cell populations likely had access to a lower concentration of hematite-derived soluble Fe(II) than the cells attached to hematite.

Hydrogenase activity was stimulated by $\mathrm{Fe}$ supplied as hematite for attached sulfate-reducing cells and $\mathrm{FeCl}_{2}$ for suspended pyruvate-fermenting cells, respectively. In the case of sulfate-reducing cells, the enhanced activity in the hematite-associated population may be a result of the $\mathrm{Fe}$ (II) concentration at the cell-mineral interface which would presumably differ from the bulk phase [5]. Analysis of the pyruvate-grown cells with hematite was challenged by high variability in the activity measurements over replicated 
Fig. 4 Microscopic analysis of $[\mathrm{NiFe}]$ hydrogenase gene expression of sulfate-reducing cells colonizing a hematite surface. a IS RT-PCR. b IS RTPCR in the absence of reverse transcriptase. $\mathbf{c}$ Incubation with labeled amplicons. DAPI-stained cells are shown in the top panel and cells labeled by IS RT-PCR with IRIS-Fuchsia dUTP of the same field are shown in the bottom panel a

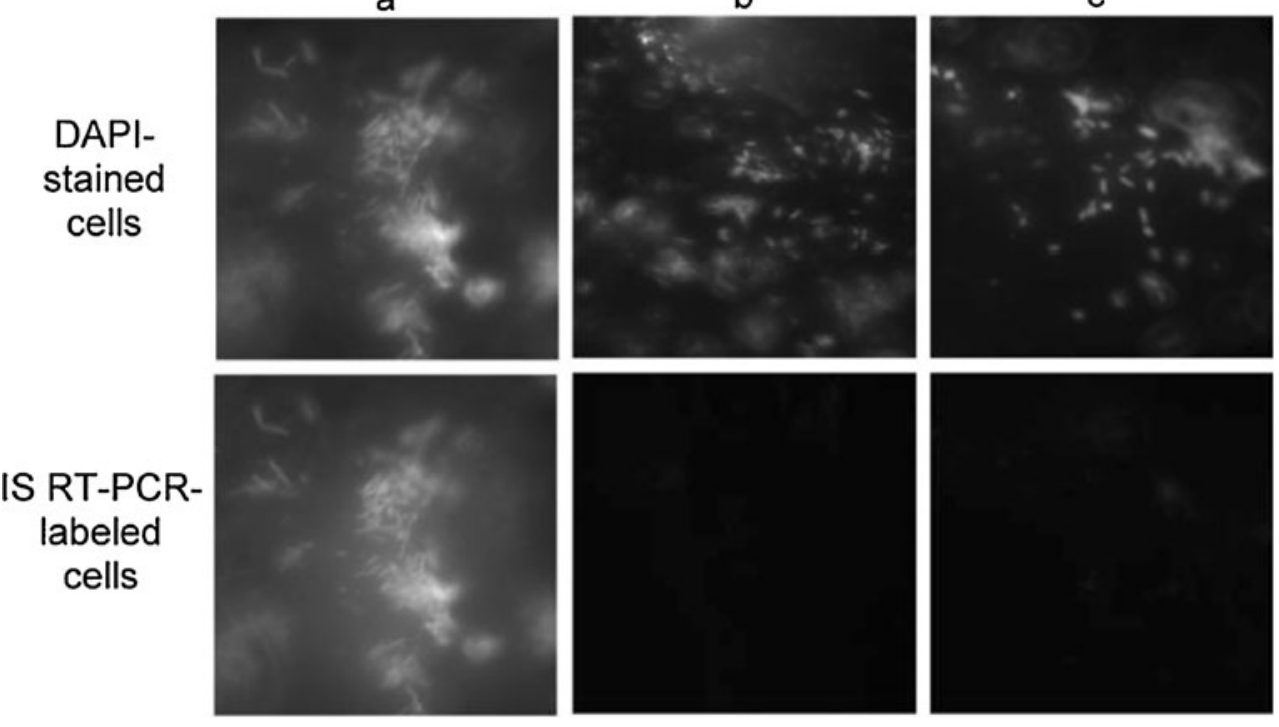

experiments; however, when the two experiments were combined, the correlation of increased activity and soluble $\mathrm{Fe}$ (II) concentration was apparent. The variation in the amount accumulated soluble Fe(II) in the cultures was likely influenced by factors of culture density or available hematite surface area.

The influence of $\mathrm{Fe}$ (II) on hydrogenase of pyruvate-grown cells was better addressed using $\mathrm{FeCl}_{2}$ which clearly identified a stimulatory effect. Regulation of hydrogenase by Fe(II) has been previously reported to function as a repressionderepression response in which activity of $D$. vulgaris (Hildenborough) was increased by addition of $90 \mu \mathrm{M}$ $(5 \mathrm{ppm}) \mathrm{Fe}(\mathrm{II})$ and reduced in the presence of $1.8 \mathrm{mM}$ (100 ppm) Fe(II) under sulfate-reducing conditions [21]. In the current study, $\mathrm{Fe}$ (II) was added during growth of the pyruvate cultures both in the presence and absence of sulfide to mimic the removal of $\mathrm{Fe}$ (II) as FeS similar to sulfatereducing cultures. The sulfide, which was added at $1 \mathrm{mM}$, was inefficient in precipitating all soluble Fe(II) and the effects of the residual $\mathrm{Fe}$ on the hydrogenase enzyme were observed by an increase in activity. Added Fe(II) stimulated activity regardless of whether cultures were grown or incubated $24 \mathrm{hrs}$ in the presence of $\mathrm{FeCl}_{2}$ (data not shown).

The cellular location of hydrogenase is critical to metabolic function and the ability of the enzyme to influence the extracellular environment. The hydrogen cycling model proposes that protons produced from the oxidation of lactate are reduced in the cytoplasm, diffuse into the periplasm, and are re-oxidized to protons by periplasmic hydrogenase [46]. For most Desulfovibrio sp., both [NiFe] and [Fe] hydrogenases are located outside of the cytoplasmic membrane [26-28] suggesting that enhanced activity may influence the $\mathrm{pH}$ and/ or redox conditions in proximity of the cell. The cellular location of hydrogenase enzymes has commonly been determined by the $\mathrm{CuCl}_{2}$ inhibition assay [27, 34, 47]. The cupric ion is both inhibitory to hydrogenase and unable to penetrate the cytoplasmic membrane so any decrease in whole cell hydrogenase upon treatment with $\mathrm{CuCl}_{2}$ can be attributed to enzymes located outside of the cytoplasmic membrane. Based on this method, the hydrogenase of $D$. desulfuricans Essex 6 was previously reported to reside in the cytoplasm [47]. Under the conditions of the current study, complete inhibition was achieved with $1 \mathrm{mM} \mathrm{CuCl}_{2}$, a fourfold increase from the concentration employed by Fitz and Cypionka [47], indicating that the enzyme(s) responsible for the measured activity reside outside of the cytoplasmic membrane. The detection of a signal peptide sequence in the gene encoding the $[\mathrm{Fe}]$ hydrogenase of Essex 6 suggested a periplasmic location for the enzyme. The signal peptide for the twin arginine translocation pathway, which exports fully folded proteins across the cytoplasmic membrane [43], was identified at the $\mathrm{N}$ terminus of the hydrogenase small subunit. The periplasmic location of hydrogenase in $D$. desulfuricans Essex 6 is consistent with the $[\mathrm{Fe}]$ and $[\mathrm{NiFe}]$ hydrogenase genes from other Desulfovibrio isolates (reviewed in [22]).

Enzyme activity and gene product abundance are often interrogated by analysis of gene expression, especially in ecological studies. Gene expression often translates to differences in gene product activity [48] and is typically reported at the population level [49-51]. Since the conditions at the microbemineral interface can differ from the culture suspension, variation in expression may be masked by bulk analysis. Few enzyme assays are capable of resolving specific activities of single cells on surfaces [48]. Since many microbially mediated mineral transformations are initiated at the single-cell or microcolony level, it is important to be able to detect and measure specific, surface-associated microbial activities at this resolution. IS RTPCR [40, 41] of hematite associated cells indicated that virtually all of the cells expressed the [NiFe] hydrogenase which is known 
to be important for sulfate reduction when lactate is provided as an electron donor [44].

The cellular location, physiological role $\left(\mathrm{H}_{2}\right.$ production and consumption), and increased activity of hydrogenase in iron oxide-associated cells may exert a significant influence on mineral transformation. The formation of the iron sulfide pyrrhotite is favored during sulfate reduction in the presence of iron oxides $[5,9]$ whereas the formation of mackinawite and greigite are favored when the Fe exists in a soluble state [7, 52]. Neal et al. [5] related the difference in FeS speciation between the soluble and solid-phase iron sources to changes at the hematite-microbe interface, namely an extremely reducing environment, low sulfide concentrations from $\mathrm{FeS}$ precipitation and potentially increased $\mathrm{Fe}(\mathrm{II})$ in addition to a lower $\mathrm{pH}$ [53]. The results of the current study demonstrate that hydrogenase activity is significantly enhanced in hematite-associated populations respiring sulfate and that the stimulation appears to be due to Fe availability rather than a generalized surface effect. Since the hydrogenase enzymes are located outside of the cytoplasmic membrane, it is plausible that the increased activity may influence the environment surrounding the cell. This study did not seek to identify the specific role or contribution of either hydrogenase enzyme; however, it is likely that the overall increased activity observed on the hematite surface could result in environmental conditions more favorable to pyrrhotite formation, i.e. the production of protons resulting in a slightly lower $\mathrm{pH}$, the production of $\mathrm{H}_{2}$ resulting in a more negative redox potential, or direct or chemically mediated dissolution of the hematite surface resulting in increased Fe concentration. Further studies are necessitated to determine if and what role hydrogenase has in biotransformation.

Acknowledgments The authors would like to thank M. Mazzola and S. L. Strauss for the review of the manuscript and A. Lasher for technical assistance. This work was funded by Inland Northwest Research Alliance grant MSU003.

\section{References}

1. Gadd GM (2010) Metals, minerals and microbes: geomicrobiology and bioremediation. Microbiology 156:609-643

2. Gadd GM (2004) Microbial influence on metal mobility and application for bioremediation. Geoderma 122:109-119

3. White C, Sayer JA, Gadd GM (1997) Microbial solubilization and immobilization of toxic metals: key biogeochemical processes for treatment of contamination. FEMS Microbiol Rev 20:503-516

4. Rickard DT, Luther GW III (2007) Chemistry of iron sulfides. Chem Rev 107:514-562

5. Neal AL, Techkarnjanaruk S, Dohnalkova A, McCready D, Peyton BM, Geesey GG (2001) Iron sulfides and sulfur species produced at hematite surfaces in the presence of sulfate-reducing bacteria. Geochim Cosmochim Acta 65:223-235

6. Benning LG, Wilkin RT, Konhauser KO (1999) Iron monosulphide stability: Experiments with sulphate-reducing bacteria. In:
Armannsson H (ed) Geochemistry of the Earth's Surface, vol. A. A. Balkema, Rotterdam, pp 429-432

7. Herbert RB, Benner SG, Pratt AR, Blowes DW (1998) Surface chemistry and morphology of poorly crystalline iron sulfides precipitated in media containing sulfate-reducing bacteria. Chem Geol 144:87-97

8. Rickard DT (1969) The microbiological formation of iron sulphides

9. Li Y-L, Vali H, Yang J, Phelps TJ, Zhang CL (2006) Reduction of iron oxides enhanced by a sulfate-reducing bacterium and biogenic $\mathrm{H}_{2} \mathrm{~S}$. Geomicrobiol J 23:103-117

10. Simon M (1985) Specific uptake rates of amino acids by attached and free-living bacteria in a mesotrophic lake. Appl Environ Microbiol 49:1254-1259

11. Grossart HP, Tang KW, Kiørboe T, Ploug H (2007) Comparison of cell-specific activity between free-living and attached bacteria using isolates and natural assemblages. FEMS Microbiol Lett 266:194-200

12. Fletcher M (1986) Measurement of glucose utilization by Pseudomonas fluorescens that are free-living and that are attached to surfaces. Appl Environ Microbiol 52:672-676

13. Li JH, Purdy KJ, Takii S, Hayashi H (1999) Seasonal changes in ribosomal RNA of sulfate-reducing bacteria and sulfate reducing activity in a freshwater lake sediment. FEMS Microbiol Ecol 28: 31-39

14. Widdel F (1988) Microbiology and ecology of sulfate- and sulfurreducing bacteria. In: Zehnder A (ed) Biology of Anaerobic Microorganisms. Wiley, New York

15. Postgate JR (1984) The Sulphate-Reducing Bacteria. Cambridge Press, Cambridge

16. Casalot L, Valette O, De Luca G, Dermoun Z, Rousset M, de Philip P (2002) Construction and physiological studies of hydrogenase depleted mutants of Desulfovibrio fructosovorans. FEMS Microbiol Lett 214:107-112

17. Pohorelic BKJ, Voordouw JK, Lojou E, Dolla A, Harder J, Voordouw $\mathrm{G}$ (2002) Effects of deletion of genes encoding Fe-only hydrogenase of Desulfovibrio vulgaris Hildenborough on hydrogen and lactate metabolism. J Bacteriol 184:679-686

18. Van den Berg WA, Van Dongen WM, Veeger C (1991) Reduction of the amount of periplasmic hydrogenase in Desulfovibrio vulgaris (Hildenborough) with antisense RNA: direct evidence for an important role of this hydrogenase in lactate metabolism. J Bacteriol 173:3688-3694

19. Odom JM, Wall JD (1987) Properties of a hydrogen-inhibited mutant of Desulfovibrio desulfuricans ATCC 27774. J Bacteriol 169:13351337

20. Hatchikian EC, Forget N, Bernadac A, Alazard D, Ollivier B (1995) Involvement of a single periplasmic hydrogenase for both hydrogen uptake and production in some Desulfovibrio species. Res Microbiol 146:129-141

21. Bryant RD, Kloeke FVO, Laishley EJ (1993) Regulation of the periplasmic [Fe] hydrogenase by ferrous iron in Desulfovibrio vulgaris (Hildenborough). Appl Environ Microbiol 59:491-495

22. Vignais PM, Billoud B (2007) Occurrence, classification, and biological function of hydrogenases: An overview. Chem Rev 107: 4206-4272

23. De Luca G, de Philip P, Dermoun Z, Rousset M, Vermeglio A (2001) Reduction of technetium(VII) by Desulfovibrio fructosovorans is mediated by the nickel-iron hydrogenase. Appl Environ Microbiol 67:4583-4587

24. Lovley DR, Roden EE, Phillips EJP, Woodward JC (1993) Enzymatic iron and uranium reduction by sulfate-reducing bacteria. Mar Geol 113:41-53

25. Chardin B, Giudici-Orticoni M-T, Luca G, Guigliarelli B, Bruschi M (2003) Hydrogenases in sulfate-reducing bacteria function as chromium reductase. Appl Microbiol Biotechnol 63:315-321

26. Vignais PM, Billoud B, Meyer J (2001) Classification and phylogeny of hydrogenases. FEMS Microbiol Rev 25:455-501 
27. Nivière V, Bernadac A, Forget $\mathrm{N}$, Fernández VM, Hatchikian CE (1991) Localization of hydrogenase in Desulfovibrio gigas cells. Arch Microbiol 155:579-586

28. Fauque G, Peck HD Jr, Moura JJG, Huynh BH, Berlier Y, DerVartanian DV, Teixeira M, Przybyla AE, Lespinat PA, Moura I, LeGall J (1988) The three classes of hydrogenases from sulfate-reducing bacteria of the genus Desulfovibrio. FEMS Microbiol Rev 54:229-344

29. Meyer J (2007) [FeFe] hydrogenases and their evolution: a genomic perspective. Cell Mol Life Sci 64:1063-1084

30. Burlage RS, Atlas R, Stahl D, Geesey G, Sayler G (1998) Techniques in Microbial Ecology. Oxford University Press, New York

31. Stams AJM, Grolle KCF, Frijters CTM, van Lier J (1992) Enrichment of thermophilic propionate-oxidizing bacteria in syntrophy with Methanobacterium thermoautotrophicum or Methanobacterium thermoformicicum. Appl Environ Microbiol 58:346-352

32. Cammack R, Fernandez VM, Hatchikian EC (1994) Nickel-iron hydrogenase. Meth Enzymol 243:43-68

33. Yu L, Wolin MJ (1969) Hydrogenase measurement with photochemically reduced methyl viologen. J Bacteriol 98:51-55

34. Cypionka H, Dilling W (1986) Intracellular localization of the hydrogenase in Desulfotomaculum orientis. FEMS Microbiol Lett $36: 257-260$

35. Stookey LL (1970) Ferrozine-a new spectrophotometric reagent for iron. Anal Chem 42:779-781

36. Gbur EE, Stroup WW, McCarter KS, Durham S, Young LJ, Christman M, West M, Kramer M (2012) Analysis of Generalized Linear Mixed Models in the Agricultural and Natural Resources Sciences. American Society of Agronomy, Madison

37. Ausabel FM, Brent R, Kingston RE, Moore DD, Seidman JG, Smith JA, Struhl K (1997) Current protocols in molecular biology. John Wiley and Sons, Inc, New York

38. Wawer C, Muyzer G (1995) Genetic diversity of Desulfovibrio spp. in environmental samples analyzed by denaturing gradient gel electrophoresis of [NiFe] hydrogenase gene fragments. Appl Environ Microbiol 61:2203-2210

39. Hatchikian EC, Magro V, Forget N, Nicolet Y, Fontecilla-Camps J (1999) Carboxy-terminal processing of the large subunit of [Fe] hydrogenase from Desulfovibrio desulfuricans ATCC 7757. J Bacteriol 181:2947-2952

40. Neal AL, Clough LK, Perkins TD, Little BJ, Magnuson TS (2004) In situ measurement of $\mathrm{Fe}(\mathrm{III})$ reduction activity of Geobacter pelophilus by simultaneous in situ RT-PCR and XPS analysis. FEMS Microbiol Ecol 49:163-169

41. Magnuson TS, Neal AL, Geesey GG (2004) Combining in situ reverse transcriptase polymerase chain reaction, optical microscopy, and X-ray photoelectron spectroscopy to investigate mineral surfaceassociated microbial activities. Microb Ecol 48:578-588

42. Hall TA (1999) BioEdit: a user-friendly biological sequence alignment editor and analysis program for Windows 95/98/NT. Nucleic Acid S 41:95-98

43. Wu L-F, Ize B, Chanal A, Quentin Y, Fichant G (2000) Bacterial twin-arginine signal peptide-dependent protein translocation pathway: evolution and mechanism. J Mol Microbiol Biotechn 2: 179-189

44. Steger JL, Vincent C, Ballard JD, Krumholz LR (2002) Desulfovibrio sp. genes involved in the respiration of sulfate during metabolism of hydrogen and lactate. Appl Environ Microbiol 68:1932-1937

45. van Loosdrecht MC, Lyklema J, Norde W, Zehnder AJ (1990) Influence of interfaces on microbial activity. Microbiol Mol Biol Rev 54:75-87

46. Odom JM, Peck HD (1981) Hydrogen cycling as a general mechanism for energy coupling in the sulfate-reducing bacteria, Desulfovibrio $\mathrm{sp}$. FEMS Microbiol Lett 12:47-50

47. Fitz RM, Cypionka H (1989) A study on electron transport-driven proton translocation in Desulfovibrio desulfuricans . Arch Microbiol 152:369-376

48. Baty AM III, Eastburn CC, Diwu Z, Techkarnjanaruk S, Goodman AE, Geesey GG (2000) Differentiation of chitinaseactive and non-chitinase-active subpopulations of a marine bacterium during chitin degradation. Appl Environ Microbiol $66: 3566-3573$

49. Meckenstock R, Steinle P, van der Meer JR, Snozzi M (1998) Quantification of bacterial mRNA involved in degradation of 1,2,4trichlorobenzene by Pseudomonas sp. strain P51 from liquid culture and from river sediment by reverse transcriptase PCR (RT/PCR). FEMS Microbiol Lett 167:123-129

50. Miskin IP, Farrimond P, Head IM (1999) Identification of novel bacterial lineages as active members of microbial populations in a freshwater sediment using a rapid RNA extraction procedure and RTPCR. Microbiology 145:1977-1987

51. Wilson MS, Bakermans C, Madsen EL (1999) In situ, real-time catabolic gene expression: extraction and characterization of naphthalene dioxygenase mRNA transcripts from groundwater. Appl Environ Microbiol 65:80-87

52. Gramp JP, Bigham JM, Jones FS, Tuovinen OH (2010) Formation of Fe-sulfides in cultures of sulfate-reducing bacteria. J Hazard Mater 175:1062-1067

53. Jeffrey R, Melchers RE (2003) Bacteriological influence in the development of iron sulphide species in marine immersion environments. Corros Sci 45:693-714 